\title{
Kunnissa kuunnellaan: asiakasosallisuus puheviestijän pelikenttänä
}

\section{Elina Antikainen}

Puheviestinnän asiantuntijuutta tarvitaan vahvasti erilaisissa työpaikoissa, joissa palveluita tarjotaan asiakaslähtöisyys strategisena kärkenä. Yksi alamme tärkeä näytön paikka on piilotettu kuntaorganisaatioihin. Kunta saattaa vaikuttaa työnantajana jokseenkin vieraalta puheviestinnän asiantuntijan näkökulmasta. Miten vuorovaikutus näkyy kuntatyössä ja miten sitä voidaan kehittää?

\section{Puheviestinnän asiantuntijan roolit kuntaorganisaatiossa}

Puheviestinnän asiantuntija voi toimia julkisorganisaatioissa hyvin monen tyyppisissä rooleissa, sillä ammattitaidon kirjo on monimuotoinen. Asiantuntija osaa tulkita esimerkiksi erilaisia työyhteisön tilanteita, rooleja ja vuorovaikutussuhteita, kehittää toimintamalleja toiminnan sujuvoittamiseksi ja ratkaista viestinnän haasteita luomalla uusia käytäntöjä esimerkiksi asiakkaiden ja organisaation väliseen viestintään. Ihmisten välisen vuorovaikutuksen asiantuntija hallitsee esiintymisen eri tilanteissa ja osaa toimia muun muassa konsulttina, neuvottelijana ja kokemustiedon tulkkina eri osapuolten välillä.

Roolit ovat kokemukseni mukaan jossain määrin sidoksissa työtehtävän sisältöön ja tarkoitukseen. Usein voidaan ajatella, että viestinnän ammattilaisen toimintakenttä on kunnassa aukottomasti viestintäyksikössä, jossa tehtävien pääpaino on vaikkapa PR-toiminnan koordinoinnissa tai viestintästrategian kehittämisessä. Kutsun tätä ilmiötä tässä artikkelissa omalla termilläni lokeroajatteluksi. Tällainen ajattelu jakaa henkilöt nimellisiin toimintayksiköihin sen mukaan, mille alueelle heidän osaamisensa pääasiassa voidaan lokeroida. Puheviestinnän asiantuntijuus saattaa olla kuntaorganisaatioissa vieras käsite, eikä sen ulottuvuuksia ehkä osata hahmottaa vielä laajemmalti. Vuorovaikutuksen ammattilaiselle hedelmällistä pelikenttää on kuitenkin kylvettynä myös muihin kunnan asiantunti- 
jatehtäviin kuin perinteisiin organisatorisiin lokeroihin.

Vuorovaikutuksen asiantuntijan osaaminen voi tulla näkyväksi esimerkiksi tehtävissä, joissa tarvitaan tietoa ja konsultointitukea päätöksentekoprosessien helpottamiseksi. Näitä rooleja voidaan kutsua tarkemmin myös termeillä neuvonantaja (advisor) ja päätöksentekoprosessin helpottaja (facilitator) (Mykkänen \& Vos 2014). Mykkäsen ja Vosin (2014) mukaan neuvonantajan tehtävä on muun muassa kerätä ja jakaa tietoa, kehittää työyhteisöä vuorovaikutteisemmaksi sekä edistää eettistä viestintää päätöksenteossa. Neuvonantaja voi myös luoda viestintäosaamisellaan ratkaisuja organisaation muutostilanteissa. Prosessin helpottaja taas tuo sidosryhmien näkemykset tai kokemukset osaksi päätöksentekoa.

Kuinka roolit näkyvät konkreettisesti työssä? Puheviestinnän asiantuntijan osaaminen on tärkeää prosessin koordinoinnissa varsinkin kuntien muutostilanteissa, joissa on pystyttävä ennakoimaan kuntalaisten palvelutarpeet ja reagoimaan monimutkaisiin rakennemuutoksiin organisaatiossa. Kunnassa alan asiantuntijan tärkein rooli voi olla tarjota asiakastyötä tekeville ja sitä kehittäville, johdolle sekä päättäjille tarvittavaa tietoa toiminnan kehittämistä varten. Organisaatiolle tuodaan aktiivisesti keskusteluun ajankohtaisia kehittämiskohteita, joita kuntalaiset tai vaikkapa henkilöstö ovat nostaneet esille. Puheviestinnän asiantuntija osaa etsiä ja nostaa esiin näitä aiheita toimien eräänlaisena viestinviejänä osapuolten välillä.

Olen havainnut, että tällaisessa työssä tarvitaan hyviä vuorovaikutustaitoja, roolien ymmärrystä, muuntautumiskykyä, innovatiivisuutta, nopeaa reagointikykyä ja kykyä tuottaa tietoa vaihteleville kohderyhmille. Töitä tehdään paljon ryhmissä ja tiimeissä keskustellen eri toimijoiden kanssa, missä ihmisten välisen vuorovaikutuksen ymmärrys korostuu. Tämän tyyppisessä työssä voidaan havaita sekoitus molempia aiemmin mainittuja Mykkäsen ja Vosin (2014) määrittelemiä rooleja yksinkertaistettuna esimerkiksi seuraavasti: tietoa muodostetaan vuorovaikutuksessa kuntalaisten kanssa, tieto analysoidaan ja viedään päätöksenteon pohjaksi tarvittaville tahoille ja tiedosta jalostetaan konkreettisia kehittämiskohteita vuorovaikutuksessa päättävien tahojen kanssa. Onnistunut prosessi palvelee strategisten tavoitteiden toteutumista ja edistää avointa vuorovaikutusta palvelujen kehittämisessä.

\section{Asiakkaiden ja puheviestijän välinen vuorovaikutus}

Asiakasosallisuuden kehittäminen on noussut vahvaksi puheenaiheeksi kuntatyössä ja sitä painotetaan erilaisissa strategioissa yhä enemmän. Päätöksenteon toivotaan tapahtuvan entistä avoimemmin, ja kuntalaisten ääni 
on saatava kuuluviin palveluiden kehittämisessä. Kuntalais- tai asiakasosallisuudesta voitaneen puhua laajasti myös kokemusasiantuntijuutena. Puheviestinnän ammattilaisen asiantuntemusta tarvitaan varsinkin tilanteissa, joissa kokemusasiantuntijoilta pyydetään tietoa vuorovaikutuksessa toisten kanssa.

Kokemusasiantuntijuutta erittelevä terminologia on hyvin monimuotoista, mutta laajasti katsottuna kokemusasiantuntijaa voidaan kuvata henkilöksi, jolla on oma tarinansa jostain aiheesta ja joka kertoo tästä kokemuksestaan palvelujen kehittäjille. Yksi tällaista henkilöä luonnehtiva termi voi olla kehittäjäasiakas (Kallinen 2014). Kokemusasiantuntijuuden ymmärtäminen näyttäisi olevan jokseenkin uusi asia julkissektorilla. Tällä sektorilla ei vielä ehkä ole yhtä herkkää taipumusta hyödyntää kokemusasiantuntijuutta kuin yksityisillä palveluntuottajilla, mutta ilmiö on rantautumassa hiljalleen myös julkiselle puolelle (Kallinen 2014). Toiminta voi olla hyvinkin järjestäytynyttä tai se voi olla hankalasti ymmärrettävä kenttä monimuotoisine osallistumismenetelmineen. Olen havainnut, että julkisella sektorilla, kuten kunnissa, kokemusasiantuntijuus ilmenee tällä hetkellä useimmiten erilaisina tapoina ja menetelminä kerätä asiakaskokemuksia.

Kuntaliiton teettämän kyselyn mukaan erilaiset kuntalaistilaisuudet ovat yleisin tapa kartoittaa kuntalaismielipiteitä (Pekola-Sjöblom 2013). Nämä voivat olla suuriakin joukkoja osallistavia tapahtumia, joissa kuntalaisilla on mahdollisuus vaikkapa kysellä kuntapäättäjiltä eri aiheista tai saada tietoa kunnan asioista. Kuitenkin kyselystä selviää, että pienemmässä mittakaavassa toteutettavat kuntalaishaastattelut ja -raadit ovat tässä tarkoituksessa vähiten hyödynnettyjä tiedonkeräyksen kanavia (Pekola-Sjöblom 2013). Olen havainnut, että jokaisessa tilaisuudessa on kuitenkin mahdollista saada monipuolista kokemustietoa, kunhan suunnittelussa panostetaan keskustelevaan otteeseen eikä tilaisuus jää pelkäksi tiedonanto- ja kyselytunniksi.

Myös asiakas- ja kuntalaiskyselyitä hyödynnetään kunnissa runsaasti muihin menetelmiin verrattuna (Pekola-Sjöblom 2013). Tulevaisuudessa tarvitaan kyselytutkimusten lisäksi myös muita menetelmiä, jotta kokemuksia on mahdollista saada talteen mahdollisimman monipuolisesti ja autenttisesti. Näyttää siltä, että vuorovaikutteiset kokemuksia kartoittavat kuntalaistilaisuudet ovat hiukan harvinaisempia kuin perinteiset kyselyt, mutta ne ovat nousemassa uuteen arvoon palveluiden kehittämisessä.

Kuntasektorilla puheviestijät voivat toimia asiakaskokemusten tulkkina. Puheviestinnän asiantuntijalla on vahva teoreettinen ja kokemuksellinen tietopohja ihmisten välisestä vuorovaikutuksesta, minkä ansiosta 
asiakkaita on luonteva kohdata keskusteluun pohjautuvissa tilanteissa, joissa jaetaan kokemuksia toisten kanssa. Tilanteessa tarvitaan keskustelun vetäjältä sekä ryhmien vuorovaikutuksen tuntemusta, luontevaa muuntautumiskykyä että tutkivaa otetta. Lisäksi on osattava huomioida kokemusasiantuntijoiden erityispiirteitä tai tarpeita ja tuottaa heille myös positiivinen osallistumiskokemus. Yksi esimerkki näistä tilanteista kunnissa ovat asiakasfoorumit. Foorumit ovat kasvattamassa hiljalleen suosiotaan ja tulossa tutuiksi kunnille, vaikka ovatkin vielä harvemmin hyödynnetty tapa kerätä asiakaskokemuksia. Tällaisilla foorumeilla kuntalaiskokemuksia jaetaan ja pohditaan yhteisessä keskustelussa toisten kanssa erikokoisissa ryhmissä. On monia tapoja järjestää asiakasfoorumeita, mutta yhteistä tavoille näyttäisi olevan se, että kokemusten keräää johtaa ryhmän keskustelua osittain strukturoidusti tarpeellisten teemojen mukaan. Puheviestinnän ammattilainen osaa ohjata keskustelua luontevasti eteenpäin ja luoda tilanteeseen asiakkaille mukavan ilmapiirin.

Kuinka kokemustieto lopulta muotoutuu puheviestinnän osaajan toimesta? Kokemustiedon kerääjä vastaa siitä, että tietoa käsitellään eettisten periaatteiden mukaan ja pyrkii säilyttämään kertojan äänen kokemuksia tulkitessaan. Puheviestinnän asiantuntija voi havaita ja nostaa aineistosta tarkastelun alaiseksi tarkemmin vuorovaikutukseen liittyviä aiheita, joita voi olla oleellista ottaa huomioon palvelujen kehittämisessä. Kokemustieto jalostetaan käyttökelpoisiksi kokonaisuuksiksi sille kohderyhmälle, joka tulee tietoa käyttämään. Tietoa voidaan raportoida eri tavoin esimerkiksi henkilöstölle ja päättäjille kehittämistoimenpiteitä varten. Lisäksi puheviestinnän osaaja voi koordinoida erilaisia jatkokeskusteluja liittyen siihen, kuinka kerätyn kokemustiedon pohjalta voidaan kehittää konkreettisia toimenpiteitä. Toimenpiteiden ideointi tapahtuu usein erilaisissa ryhmissä tai tiimeissä. Tällaisissa jatkokehittämistilaisuuksissa painottuvat jälleen alan asiantuntijan kyky ohjata ryhmäkeskustelua, luotsata ideoita ja jäsentää ajatuksia.

\section{Esimerkki kokemusasiantuntijuuden käytöstä kuntasektorilla}

Kokemusasiantuntijuutta tulisi hyödyntää enemmän julkissektorin palvelujen kehittämisessä. Esimerkiksi Imatran kaupunki on alkanut käyttää kokemustietoa kehittämisen tukena aiempaa aktiivisemmin viime aikoina. Kunnassa on panostettu asiakaskyselyjen lisäksi muun muassa vuorovaikutteisiin kokemusfoorumeihin. Foorumit ovat koonneet yhteen eri asiakas- tai kuntalaisryhmiä tarpeen mukaan. 
Vuonna 2013 kunnassa toteutettiin kuntouttavan työtoiminnan asiakasfoorumi yhteistyössä kolmannen sektorin yhdistysten kanssa. Foorumin tulokset vietiin toimialalla vahvasti myös käytäntöön: järjestettiin useampia ideointipäiviä moniammatillisissa työryhmissä, laadittiin konkreettisia toimenpiteitä yhteisten palveluprosessien kehittämiseksi ja jaettiin tietoa tilaajalautakunnalle päätöksenteon tueksi. Foorumitoiminta on laajentunut vuonna 2014 kutsuen kokoon myös laajempia kuntalaisryhmiä. Foorumitoiminnan avulla saadaan arvokasta tietoa erityisesti kuntalaisilta, joille suunnattuja palveluita on kehitettävä tehokkain toimenpitein tulevaisuuden tarpeita ennakoiden.

Imatralla nämä kehittäjäasiakkaat, kokemusasiantuntijat tai oman tarinansa kertojat ovat antaneet hyvää palautetta tilaisuuksiin osallistumisesta. Nimenomaan vuorovaikutteiset tilanteet, joissa jaetaan kokemuksia toisten kanssa, ovat osoittautuneet asiakkaiden mielestä hyviksi tavoiksi antaa palautetta, saada vertaistukea ja päästä vaikuttamaan palvelujen kehittämiseen. Tärkeää osallistujille on ollut saada oma äänensä konkreettisesti esiin kehitystyössä. Niinpä on myös tärkeää osoittaa osallistujille, kuinka kokemustietoa on konkreettisesti hyödynnetty kehittämisessä.

\section{Vuorovaikutteisen kuntalaistyön vaikutukset}

Kunnissa ollaan heräämässä siihen, että palveluiden kehittämiseksi tarvitaan yhä enemmän myös vuorovaikutuksessa jaettua ja muodostettua kokemusperäistä asiakastietoa. On esitetty, että tulevaisuudessa tarvitaan ylipäätään yhä enemmän vuorovaikutteisia työtapoja. Työelämän tarpeet näyttäisivät suuntaavan yksin suoritettavasta työstä kohti vuorovaikutteista verkostoja suosivaa toimintaa. Tärkeää tulevaisuuden työssä on asiakkaiden tarpeiden ennakointi - osataanko heidän toiveitaan ja tarpeitaan kuunnella? Organisaatioissa kehitetään runsaasti erilaisia palveluprosesseja, mutta häipyykö niistä palvelujen käyttäjien ääni? Kuuntelemisen kehittäminen on oleellinen osa onnistumista - täytyy tiedostaa ne keinot, joilla kuuntelemisessa voi kehittyä. (Juva 2014.) On osattava poimia asiakkaan kokemuksesta pieniä asioita, joiden avulla prosesseja voi parantaa (Verho 2014). Tässä on puheviestinnän ammattilaiselle erinomainen kenttä kehittää ja kehittyä.

Asiakaslähtöisellä kehittämisellä on todettu olevan positiivisia vaikutuksia osallistujien elämänlaatuun ja kokemuksiin vaikutusmahdollisuuksistaan. Asiakasosallisuuden vaikutukset voivat näkyä myös palvelun laadun parantumisena, taloudellisina säästöinä palvelujen tuottamisessa sekä henkilöstön työhyvinvoinnin parantumisena (Jäppinen \& Sallinen 2012). 
Kokemusasiantuntijuusmenetelmät voivat olla keskeinen avain prosessien kehittämiseen ja avun entistä nopeampaan saamiseen asiakkaan näkökulmasta (Kallinen 2014).

Kokemusasiantuntijatoiminnan juurruttaminen kunnan strategiseen toimintaan on haasteellista ja sen organisointiin tarvitaan suunnitelmallista koordinointia. Tällainen työ on puheviestinnän osaajalle erityinen ja uudenlainen tila toimia julkisen sektorin palvelujen kehittäjänä. $\mathrm{Pu}$ heviestinnän ammattilainen osaa toimia laajasti eri rooleissa toiminnan suunnittelussa, toteuttamisessa ja vakiinnuttamisessa. Vuorovaikutuksen ammattilainen voi osaamisellaan vaikuttaa sekä organisaation prosessien sujuvuuteen että laajemmin kuntalaisten hyvinvointiin. Tämän myötä sekä ymmärrys että arvostus vuorovaikutuksen asiantuntijuutta kohtaan kuntaorganisaatioissa voivat kasvaa.

\section{Kirjallisuus}

Juva, K. 2014. Kuuleeko kukaan? Esitelmä. Puheviestinnän päivät -kongressi 5.9.2014, Jyväskylä.

Jäppinen, T. \& Sallinen, S. 2012. Kuntalainen palvelujen kehittäjänä.

Helsinki: Suomen Kuntaliitto. Uudistuva kunta -sarja.

Kallinen, S. 2014. Esitelmä. Kokemusasiantuntijuus-seminaari 16.9.2014, Helsinki.

Mykkänen, M. \& Vos, M. 2014. Viestintäammattilaisen rooli organisaation päätöksenteossa. Esitelmä. Puheviestinnän päivät -kongressi 6.9.2014, Jyväskylä.

Pekola-Sjöblom, M. 2013. Kunnan tarjoamat osallistumis-, vaikuttamisja palautekanavat. Teoksessa S.-L. Piipponen \& M. Pekola-Sjöblom (toim.) Kuntademokratian ja -johtamisen tila valtuustokaudella 20092012. Acta nro 252. Helsinki: Suomen Kuntaliitto, 44-62.

Verho, T. 2014. Kokemuksia aluetyöpajoista. Esitelmä. Kokemusasiantuntijuus-seminaari 16.9.2014, Helsinki. 